Journal American Society of Mining and Reclamation, 2019 Vol.8, No.1

\title{
SOIL STOCKPILE SEED VIABILITY DECLINES WITH DEPTH AND IS IMPACTED BY SURFACE VEGETATION ${ }^{1}$
}

\begin{abstract}
Jennifer Buss ${ }^{2}$, Bradley D. Pinno
Abstract: Stockpiled soil will be used to operationally reclaim approximately half of the area disturbed by one oil sands mine in northern Alberta, Canada over the next few decades. However, there are concerns regarding the viability of native seeds in stockpiles relative to directly placed reclamation soil. To test the germination of seeds from a four-year-old soil stockpile, we took samples at different depths up to $90 \mathrm{~cm}$ from three surface vegetation communities (sweet clover, sow-thistle, and wheatgrass dominated). These samples were placed in the greenhouse on top of potting soil to allow any seeds to germinate for nine weeks. The highest species richness $(42 \%$ of species) and total plant abundance (68\% of all plants) were found at the surface of the stockpile $(0-10 \mathrm{~cm})$. Most of the species found in these soil samples were native $(63 \%)$ and the most abundant species was slender wheatgrass, a native grass species. Vegetation type did not affect the species richness, but there was a higher average seedling abundance in the sow-thistle treatment. The vegetation types did impact the seed-bank community at the surface of the stockpile, with the most abundant species on the surface having the most impact on the seed bank community for each respective vegetation type. However, below the surface the most abundant species in the seed bank did not always reflect the dominant surface vegetation. Using soil stockpiles for final land reclamation in the future may be an issue because of the low number of viable seeds below the surface.
\end{abstract}

Additional Key Words: seed bank, species abundance, species richness, germination

1. Oral paper presented at the 2018 National Meeting of the American Society of Mining and Reclamation, St. Louis, MO: The Gateway to Land Reclamation, June 2 - 7, 2018.

2. Jennifer Buss is a MSc Student, Renewable Resources Department, University of Alberta, Alberta, Canada. * Corresponding author (jbuss@ ualberta.ca). Bradley D. Pinno is Assistant Professor of Silviculture, Renewable Resources Department, University of Alberta, Alberta, Canada. 


\section{Introduction}

Topsoil stockpiles are created during oil sands mining when the surface soil layers are salvaged and stockpiled for later use in land reclamation. Topsoil is essential for land reclamation because it enhances growth of plants, but these piles can sometimes sit for a long time before being utilized (Ghose, 2004), potentially resulting in the loss of viable seeds and plant propagules. One of the main goals of land reclamation is to have a native and diverse plant community that is similar to the natural boreal forests that were present before disturbance (Alberta Environment, 2010). However, acquiring native plant propagules can be a challenge since many boreal forest species are unavailable commercially (Lanoue and Qualizza, 2000). Given the concern of reduced plant propagules in soil stockpiles, direct placement of fresh soil from a donor site is preferred to the use of stockpiled soil for reclamation (MacKenzie, 2012). However, stockpiled soils will have to be used to reclaim a large area of the oil sands, with one mine planning on using them to reclaim approximately half of their lease (I. Sherr, Reclamation Vegetation Specialist, Canadian Natural Resources Limited, personal communication, 2018).

In the Alberta oil sands region forest floor-mineral mix (FFMM) is one of the main types of soil that is stockpiled and used in reclamation as a cover soil (McMillan et al., 2007). FFMM is made up of the organic forest floor layer and underlying mineral soil salvaged prior to mining and is an upland forest soil (Pinno et al., 2012). Most sites in the oil sands area are being reclaimed to upland ecosystems, even though there is a limited amount of FFMM soil available (Rooney et al., 2012). Therefore, stockpiling FFMM soils may result in more of a risk to desirable plant propagules for reclamation, which is why the focus of this study is on the impacts of stockpiling FFMM soil.

Seed longevity in natural forest soil is increased at lower moisture conditions, and decreased by mechanical injury (Bewley and Black, 2012, p. 9; Moore, 1972). Stockpiling soils can result in an increase in volumetric water content, and injury to seeds through the stockpiling and placement processes, which can decrease seed viability (MacKenzie, 2013; Koch et al., 1996). Stockpiles in Australia, the United Kingdom, and the United States show a decline in the number of viable seeds with depth; stockpile age due to germination at depth; subsequent death before reaching the surface; loss of seed inputs, and seed predation (Bellairs and Bell, 1993; Dickie et al., 1988; Golos and Dixon, 2014; Harris and Birch, 1987; Iverson and Wali, 1982). 
In natural forests the abundance of viable seeds also declines with depth due to the reduction of seed input (Harper, 1977). Even though cover soil stockpiles are made up of the top 15-30 cm of the soil profile, which is high in seed density, seeds are lost at depth over time and overall stockpiles are seed-poor (MacKenzie, 2012). Most of the seed bank in undisturbed soils is in the top few centimeters of the litter and mineral layers (0-5 cm) (Fyles, 1980; Kellman, 1970; Kramer and Johnson, 1987). This results in a mixing of the surface seed-rich soils with seed-poor subsoils, which leads to burying of seeds and dilution of the seed bank when soil is stockpiled (Mackenzie and Naeth, 2007; Scoles-Sciulla and DeFalco, 2009). Overall stockpiling results in a loss of seeds at depth and a dilution of the seed bank.

Vegetation occurring on the surface of the stockpile also impacts the seed bank. This association of the above-ground vegetation and seed-bank communities has been found in naturally occurring forests as well as on soil stockpiles (Beatty, 1991; Olano et al., 2002; Rydgren and Hestmark, 1997). In the past, stockpiles were originally seeded with grass or legume species to prevent erosion and invasion by weeds, which could influence the seed bank available for reclamation (Brown and Hallman, 1984; Busby, 2014). Soil stockpiles are also more susceptible to invasion by fast growing and reproducing weedy species when they are first placed. Therefore, weedy or undesirable species may come to dominate the seedbank of stockpiled soils rather than desirable native forest species.

This study explored the effect of depth and current dominant vegetation on seed bank seedling abundance and species richness in a 4-year-old upland soil stockpile. We hypothesize that seedling abundance and species richness will decrease with depth, and that the surface vegetation will contribute to the seed-bank community with the seed bank ultimately reflecting the surface vegetation.

\section{Materials and Methods}

Samples were collected from a 4-year-old stockpile in August 2017 at an oil sands mine north of Fort McMurray, Alberta, Canada (57.31440659, -111.8648645). The stockpiled soil was originally from an upland, boreal mixed-wood site ("d" ecosite, Beckingham and Archibald, 1996). The stockpile consisted of material from multiple years of placement, with the latest placement (4 years ago) occurring on the top of the stockpile and extending past our sampling depth. 
Aboveground vegetation cover was sampled in $10 \mathrm{~m}^{2}$ plots at each sampling location with a focus on more dominant species. Based on the aboveground vegetation surveys the stockpile was sorted by unseeded volunteer vegetation types, which were each dominated by one species. The three vegetation types were: sweet clover (Melilotus sp.), perennial sow-thistle (Sonchus arvensis), and slender wheatgrass (Agropyron trachycaulum var. trachycaulum) (Fig. 1). Sites were selected based on the following vegetation type criteria: one vegetation type made up more than $30 \%$ cover of the vegetation plot, had the highest overall cover, and an average percent cover of at least $45 \%$ across all plots. Wheatgrass had an average percent cover of $47 \%$ in its respective plots, sweet clover 50\%, and sow-thistle 53\%. Across the site, three sampling blocks were identified that had each of the main vegetation types within a short distance of each other. Then, within each block in each vegetation type a soil pit was dug and a trowel was used to extract approximately $900 \mathrm{~mL}$ of soil at depths of 0-10 cm, 10-20 cm, 20-30 cm, and 80-90 cm. Two sub-samples were taken for the $0-10 \mathrm{~cm}$ depth at each pit location. The $0-10 \mathrm{~cm}$ samples were taken adjacent to the soil pit, to avoid the area of soil disturbance. In total there were nine sampling locations and 45 soil samples collected.

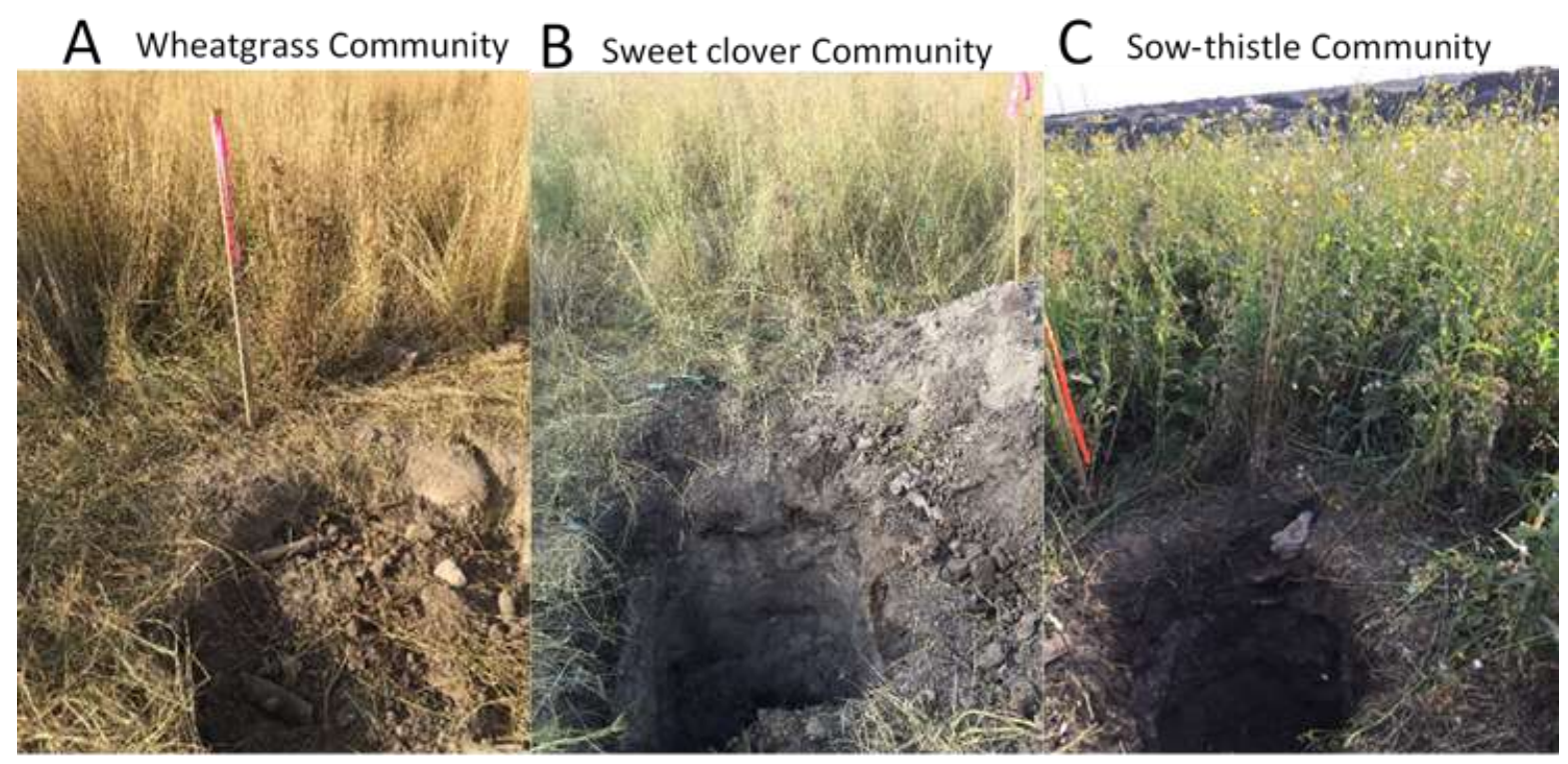

Figure 1. Soil pits for sample collection on a 4-year-old stockpile. (A) wheatgrass, (B) sweet clover, and (C) sow-thistle dominated plant communities.

Samples were stored at $4{ }^{\circ} \mathrm{C}$ (Baldwin et al., 1996; Wilson et al., 1993) for 7 weeks. It is not likely that storing the seed-bank samples at this temperature led to a decrease in viability of the 
seeds as the study area is subject to winter temperatures. However, it is possible that this storage temperature was not low enough to break the dormancy of some of the seeds. Samples were mixed thoroughly and sieved to a volume of $500 \mathrm{~mL}$ using a $4 \mathrm{~mm}$ sieve to remove any large debris. The 0-10 cm depth sub-samples were processed and placed separately. Samples were then spread over approximately $4.27 \mathrm{~L}$ of Pro-Mix potting soil in greenhouse flats $(28 \mathrm{~cm} \mathrm{x} 55 \mathrm{~cm}$ x $6 \mathrm{~cm})$ at a $1 \mathrm{~cm}$ thickness (Fig. 2). Ten control flats that contained only potting soil were also placed randomly throughout the greenhouse.

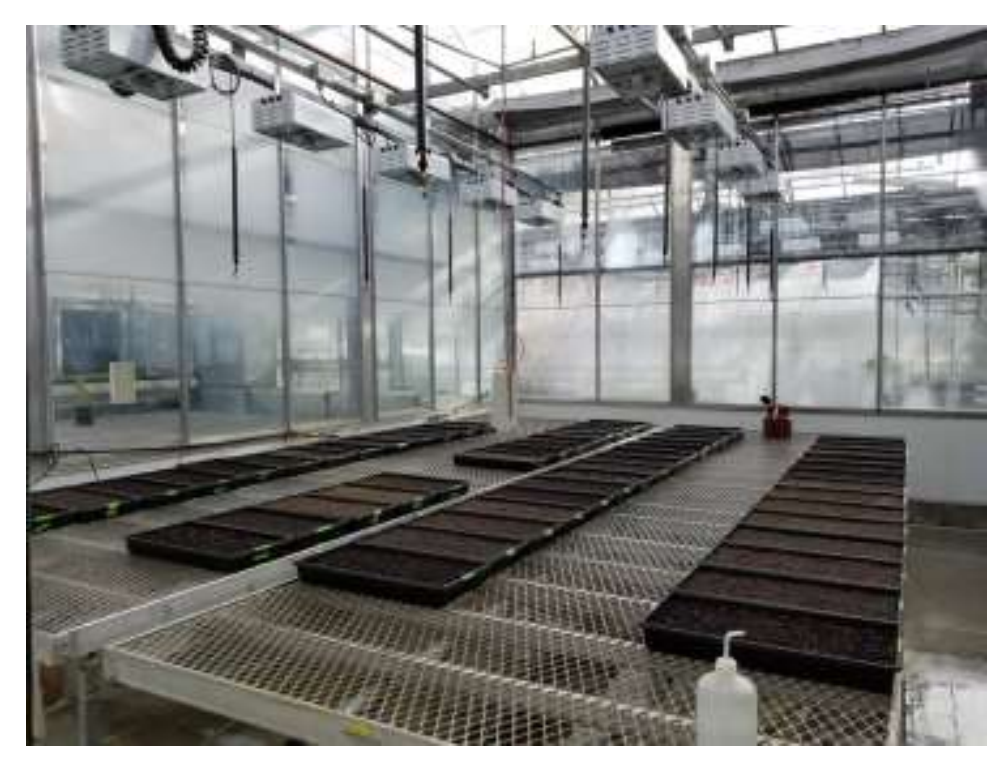

Figure 2. Greenhouse setup showing all samples placed in greenhouse flats.

The samples were placed in a greenhouse that received 16 hours of light a day, with day time/night time temperatures of $22{ }^{\circ} \mathrm{C} / 18{ }^{\circ} \mathrm{C}$, and $60 \%$ humidity. The samples were watered for 20 minutes every day. Flats were left in the greenhouse for 9 weeks, and seedling germinates were identified to the species level, counted, and removed from the greenhouse flats once a week starting on their second week growing in the greenhouse. Seedlings were not harvested until the second week to allow for seedlings to become large enough to identify. Plants were identified using the Flora of Alberta (Moss and Packer, 1983). For any individuals that could not be identified as seedlings, five identical seedlings were repotted to grow out and flower (Fig. 3). If not all the five seedlings turned out to be the same species, the ratio of individuals that were later identified as the same (\# out of five) were applied to the data to account for any possible identification mistakes. Epilobium ciliatum was present in many of the control flats, so an average across all flats was taken (five individuals) and then subtracted from all flats. Harvesting ended after nine weeks, once 
most flats did not have any new seedlings emerge for over two weeks and overall germination had ceased.

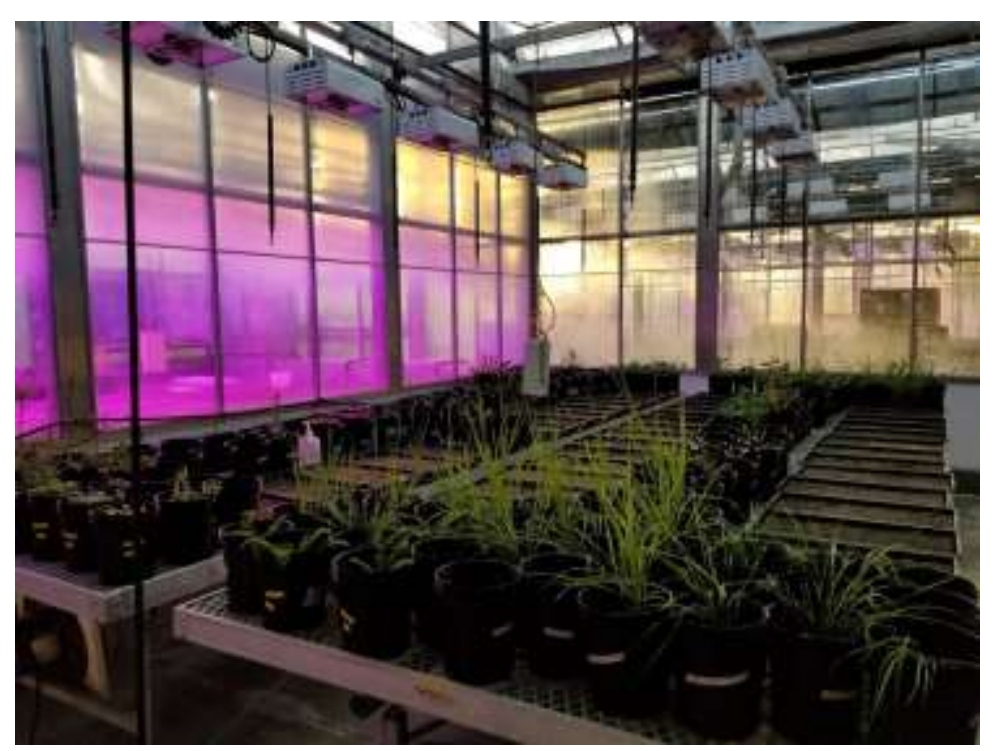

Figure 3. Greenhouse setup, including repotted plants that could not be identified initially in the greenhouse flats.

Counts from the two sub-samples taken at 0-10 cm were averaged before being analyzed. All statistical analysis was done using $\mathrm{R}$ (version 3.4.0). Seedling counts for each sample were aggregated before being analyzed using a generalized linear model (GLM) with a Poisson distribution using the Stats package in R (R Core Team, 2013). An analysis of deviance was performed on a GLM model to determine if there were any differences in seedling abundance (\# of seedlings/500 mL of soil) or species richness (\# of species/500 mL of soil) across depth or vegetation types, or if there were any interactions between the two treatments.

Multiple pairwise comparisons (Tukey's test, $\alpha=0.05$ ) were done using the Multcomp package in $\mathrm{R}$ ( $\mathrm{R}$ Core Team, 2013). The data was subset by vegetation type to determine differences in seedling abundance and species richness across depth treatments for each vegetation type. In order to compare native and non-native seedling abundance and species richness, pairwise comparisons were performed by sub-setting the data by either depth or vegetation type and then comparing the number of native individuals or species to non-native. Pairwise comparisons were also performed on non-native individuals and species across depth treatments. Non-native and native species cover in the aboveground vegetation was also compared for each of the vegetation types. 
Seed-bank communities at the $0-10 \mathrm{~cm}$ depth of the three surface vegetation treatments were compared using a non-metric multi-dimensional scaling (NMDS) ordination from the Vegan package in $\mathrm{R}$ ( $\mathrm{R}$ Core Team, 2013). A stress test was performed to determine the appropriate number of dimensions to use (3 dimensions), and Bray-Curtis was used as our distance measurement. The percentage of variability that is explained by the first dimension is 52\%, $19 \%$ for the second dimension, and 14\% for the third. Multiple response permutation (MRPP) was used to compare seed bank plant communities among vegetation treatments and sampling blocks.

\section{$\underline{\text { Results }}$}

There was a total of 15 aboveground species observed at the time of sampling (12 native, and 3 non-native). Five species that were detected in the aboveground community were not found in the seed-bank community. The three vegetation types were abundant in the seed bank (sow-thistle, wheatgrass, sweet clover) (Table 1). However, other species which were also abundant in the aboveground communities, such as Trifolium hybridum, Hordeum jubatum, and Chamerion angustifolium were present in the seed bank, but were not one of the ten most abundant species in the seed bank (Table 1, Table 2).

A total of 62 species germinated from the stockpile seed bank, with 39 native species, 14 non-natives, and 9 unidentified species. The five most common species that germinated across all treatments were Agropyon trachycaulum (slender wheatgrass, a native grass), Melilotus sp. (sweet clover, non-native forb), Glyceria striata (fowl manna grass, native grass), Potentilla norvegica (rough cinquefoil, native forb), and Sonchus arvensis (perennial sow-thistle, non-native forb). These species made up $77 \%$ of the total seedling abundance.

Table 1: Average total aboveground cover, stratified by aboveground vegetation community type. Highlighted boxes represent aboveground covers for a species in their respective vegetation community. Species included were the most abundant in the aboveground communities.

\begin{tabular}{lrrr}
\hline Aboveground Species & Sow-thistle Community & Sweet clover Community & Wheatgrass Community \\
\hline Agropyron trachycaulum & 2.7 & 4.5 & $\mathbf{4 7}$ \\
Melilotus sp. & 3.3 & $\mathbf{5 0}$ & 5.7 \\
Sonchus arvensis & $\mathbf{5 3 . 3}$ & 6.7 & 4 \\
Trifolium hybridum & 0.7 & 13.3 & 10 \\
Calamagrostis canadensis & 4.7 & 0.7 & 3.3 \\
Hordeum jubatum & 1 & 5.7 & 3.3 \\
Chamerion angustifolium & 7.3 & 2.3 & 0 \\
\hline
\end{tabular}


Table 2. Proportion (\%) of total seedling abundance sorted by vegetation type. Highlighted lines represent seed-bank abundances for the same dominant aboveground vegetation species.

\begin{tabular}{lcccccccccccc}
\hline & \multicolumn{3}{c}{ Sow-thistle Community } & \multicolumn{3}{c}{ Sweet clover Community } & \multicolumn{3}{c}{ Wheatgrass Community } \\
Seed bank species & $0-10$ & $10-20$ & $20-30$ & $80-90$ & $0-10$ & $10-20$ & $20-30$ & $80-90$ & $0-10$ & $10-20$ & $20-30$ & $80-90$ \\
\hline Agropyron trachycaulum & 1.49 & 0.28 & 0.69 & 0.03 & 4.73 & 0.00 & 0.03 & 0.00 & $\mathbf{6 . 9 9}$ & $\mathbf{0 . 2 8}$ & $\mathbf{0 . 0 0}$ & $\mathbf{0 . 0 6}$ \\
Melilotus sp. & 0.03 & 0.00 & 0.00 & 0.00 & $\mathbf{2 . 3 7}$ & $\mathbf{0 . 0 0}$ & $\mathbf{0 . 0 0}$ & $\mathbf{0 . 0 0}$ & 0.98 & 0.00 & 0.00 & 0.00 \\
Sonchus uliginosus & $\mathbf{2 . 9 9}$ & $\mathbf{0 . 1 7}$ & $\mathbf{0 . 1 9}$ & $\mathbf{0 . 0 6}$ & 0.77 & 0.08 & 0.06 & 0.00 & 0.25 & 0.06 & 0.03 & 0.00 \\
Potentilla norvegica & 3.92 & 3.38 & 5.04 & 0.19 & 2.06 & 0.11 & 0.19 & 0.00 & 1.81 & 0.11 & 0.03 & 0.00 \\
Urtica dioca & 0.03 & 0.03 & 0.11 & 0.00 & 0.22 & 0.72 & 0.19 & 0.03 & 0.01 & 0.00 & 0.00 & 0.03 \\
Epilobium ciliatum & 0.33 & 0.03 & 0.25 & 0.17 & 0.40 & 0.22 & 0.11 & 0.61 & 0.19 & 0.00 & 0.00 & 0.00 \\
Glyceria striata & 0.97 & 0.30 & 0.22 & 0.08 & 1.47 & 0.22 & 0.06 & 0.30 & 0.98 & 0.22 & 0.14 & 0.03 \\
Mitella nuda & 0.00 & 0.00 & 0.00 & 0.00 & 0.00 & 0.03 & 0.00 & 0.08 & 0.00 & 0.03 & 0.00 & 0.00 \\
Plantago major & 0.00 & 0.03 & 0.36 & 0.00 & 0.00 & 0.00 & 0.00 & 0.00 & 0.04 & 0.00 & 0.00 & 0.00 \\
Lepidium densiflorum & 0.03 & 0.08 & 0.08 & 0.00 & 0.87 & 0.00 & 0.00 & 0.00 & 1.34 & 0.11 & 0.03 & 0.00 \\
\hline
\end{tabular}

Total seedling abundance differed by depth and vegetation type, but plant communities did not differ by block (Table 3, $\mathrm{p}=0.788$ ). Total seedling abundance was greatest from the surface of the stockpile, with the $0-10 \mathrm{~cm}$ depth containing $68 \%$ of the total number of germinated seedlings ( $\mathrm{p}<0.001$ for all depth treatments), and all vegetation types having a higher seedling abundance at 0-10 cm (Fig. 4a). The sow-thistle treatment had the highest average seedling abundance when compared with the wheatgrass $(\mathrm{p}<0.001)$ and sweet clover $(\mathrm{p}=0.002)$ vegetation types. The wheatgrass and sweet clover treatments showed no difference in average seedling abundance $(\mathrm{p}=0.142)$.

Table 3: Analysis of deviance table for a GLM model including depth and vegetation type for seedling abundance and species richness.

\begin{tabular}{lccc}
\hline Seedling Abundance & df & Deviance Residual & $\mathrm{p}$ \\
\hline Depth & 3 & 2697.63 & $<0.001$ \\
Veg.Type & 2 & 30.87 & $<0.001$ \\
Depth:Veg.Type & 6 & 465.25 & $<0.001$ \\
& & & \\
Species Richness & $\mathrm{df}$ & Deviance Residual & $\mathrm{p}$ \\
\hline Depth & 3 & 59.19 & $<0.001$ \\
Veg.Type & 2 & 0.851 & 0.653 \\
Depth:Veg.Type & 6 & 11.396 & 0.077 \\
\hline
\end{tabular}

There were more native individuals than non-native individuals across all depth treatments ( $\mathrm{p}<0.001$ for all depths). The proportion of native individuals at $0-10 \mathrm{~cm}$ was $75 \%$ of all individuals, $90 \%$ at $10-20 \mathrm{~cm}, 90 \%$ at $20-30 \mathrm{~cm}$, and $87 \%$ at $80-90 \mathrm{~cm}$. There was a higher number of non-native individuals at the $0-10 \mathrm{~cm}$ depth compared to the other depth treatments $(\mathrm{p}<0.05$ for 
all comparisons). All vegetation types also had more native individuals than non-native $(\mathrm{p}<0.001$ for all comparisons). There were $74 \%$ native individuals in the sow-thistle, $74 \%$ in the sweet clover, and $86 \%$ in the wheatgrass.

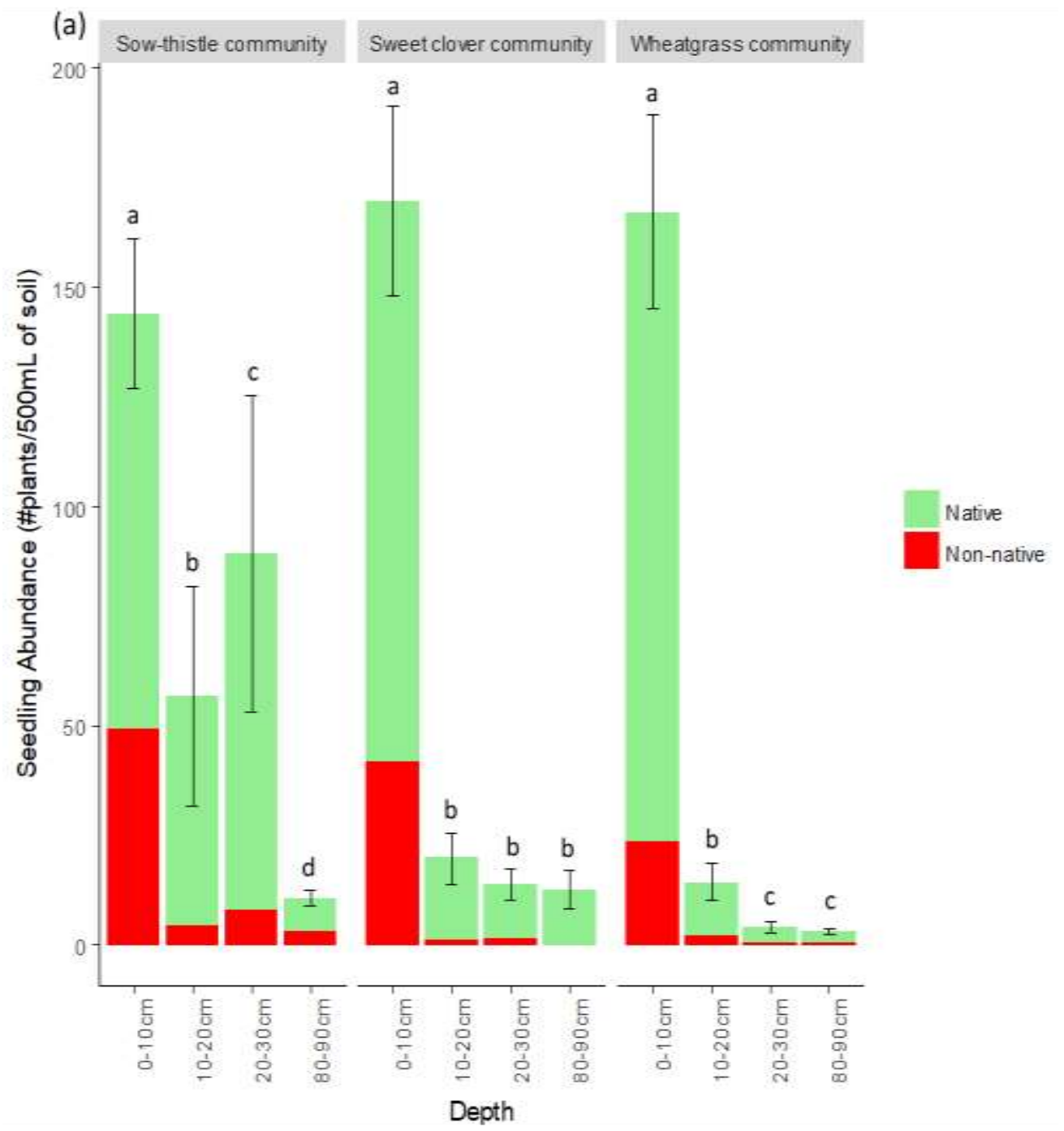

The figure caption is on next page.

Species richness followed a similar pattern as abundance, with a decrease in richness with depth (Table 3). However, there was no difference among vegetation types. The species richness was highest at the $0-10 \mathrm{~cm}$ depth ( $42 \%$ of species). The wheatgrass and sweet clover vegetation types had differences in species richness between the 0-10 $\mathrm{cm}$ and 80-90 cm depths while the sowthistle treatment showed no differences in species richness across any of the depths (Fig. 4b). 


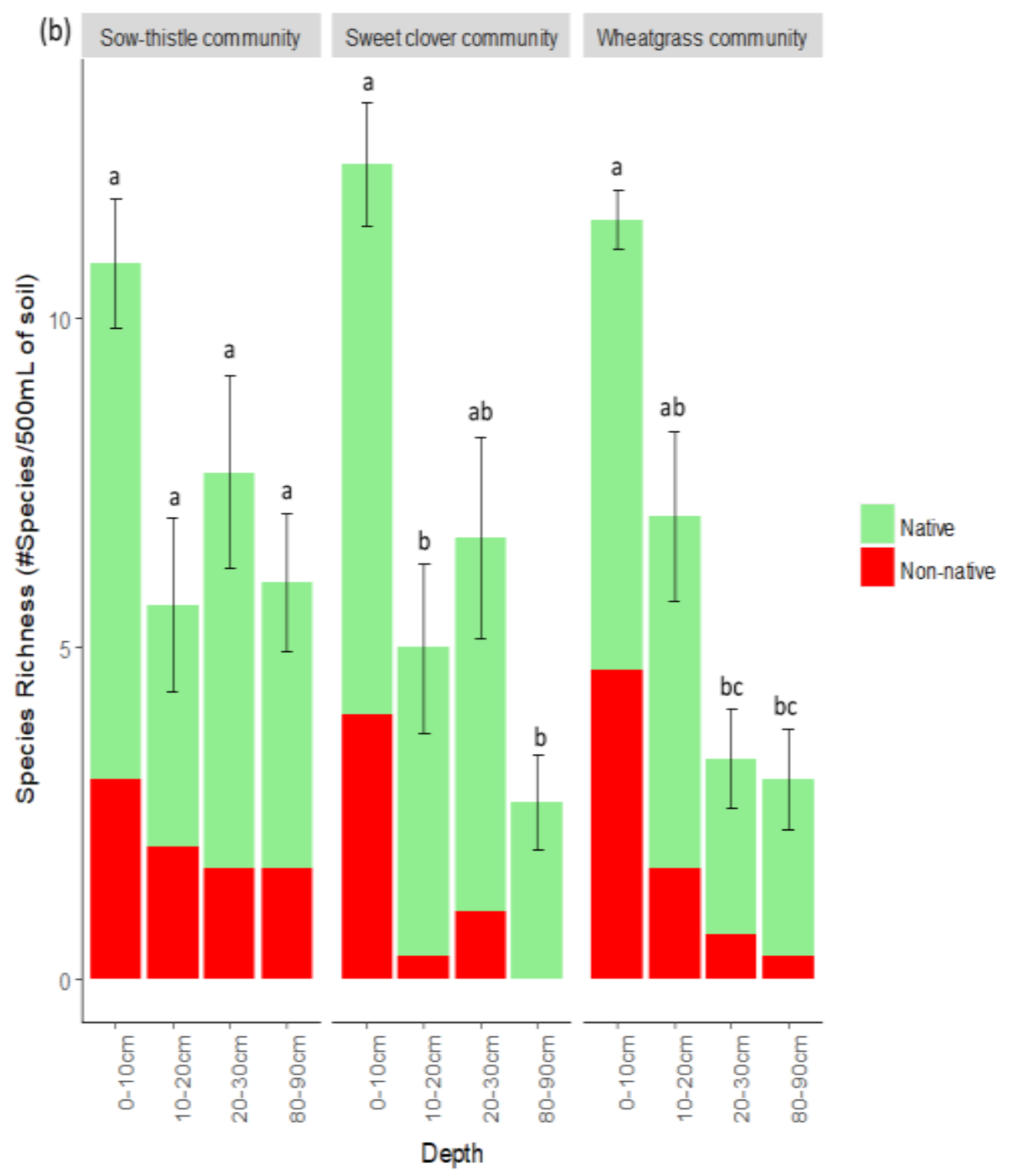

Figure 4. (a) Seedling abundance/500 $\mathrm{mL}$ of sample soil (b) and species richness/500 mL of sample soil across different depths, vegetation treatments and native/non-native species. Values are mean and standard error. Letters represent significant differences (Tukey's test, $\alpha=0.05$ ) in total seedling abundance and species richness between depth treatments within each individual surface vegetation type.

There were also more native species than non-native across all depth treatments $(\mathrm{p}<0.001$ for all depth treatments). At $0-10 \mathrm{~cm}, 66 \%$ of species occurring were native, $77 \%$ at $10-20 \mathrm{~cm}, 81 \%$ at $20-30 \mathrm{~cm}$ and $82 \%$ at $80-90 \mathrm{~cm}$. The $0-10 \mathrm{~cm}$ depth had a higher number of non-native species than the other depths ( $\mathrm{p}<0.05$ for all comparisons). There were also more native species across all vegetation types $(\mathrm{p}<0.001$ for all vegetation types). For the sow-thistle vegetation type, $72 \%$ of species were native, $76 \%$ for sweet clover, and $67 \%$ for wheatgrass. 
The aboveground vegetation showed a slightly different trend, with an increased average native species cover across the native wheatgrass vegetation type (57\% native species), but an increased non-native species cover in both the non-native sow-thistle (57\% non-native) and sweet clover (71\% non-native) vegetation types ( $\mathrm{p}<0.001$ for all vegetation types).

Seed-bank communities from the 0-10 cm depth differed among surface vegetation types ( $p=0.032$, Fig. 5), with the most abundant aboveground species at the time of sampling generally having the highest impact on the seed-bank community of that vegetation type. The NMDS ordination shows grouping of the seed-bank community by aboveground vegetation type. The vector overlays of Melilotus sp. (sweet clover), A. trachycaulum (wheatgrass), and S. uliginosus (sow-thistle) were the longest vectors corresponding to their respective aboveground vegetation type (sweet clover, wheatgrass, and sow-thistle). Therefore Melilotus sp. had the biggest impact on the sweet clover vegetation type seed-bank community, A. trachycaulum on wheatgrass and $S$. uliginosus on sow-thistle.

A. trachycaulum was more common in the wheatgrass vegetation type, S. uliginosus in the sow-thistle, and Melilotus sp. in the sweet clover than in other treatments at 0-10 cm (Table 2). A. trachycaulum was the most abundant species across all depths in the wheatgrass treatment, except 20-30 cm, and was the most abundant species at the surface in the sweet clover treatment. Sonchus arvensis and Melilotus sp. were both the second most abundant species in their respective aboveground vegetation types (sow-thistle and sweet clover plots), but only at the surface (0$10 \mathrm{~cm})$. P. norvegica was one of the most relatively abundant species in all three vegetation types and was the most abundant species across all depth treatments in the sow-thistle vegetation treatment. At depth $(80-90 \mathrm{~cm})$, the most abundant species were Epilobium ciliatum, Glyceria striata, Urtica dioca, Potentilla norvegica and Mitella nuda, with the most abundant species at 80$90 \mathrm{~cm}$ being E. ciliatum (Table 2). 


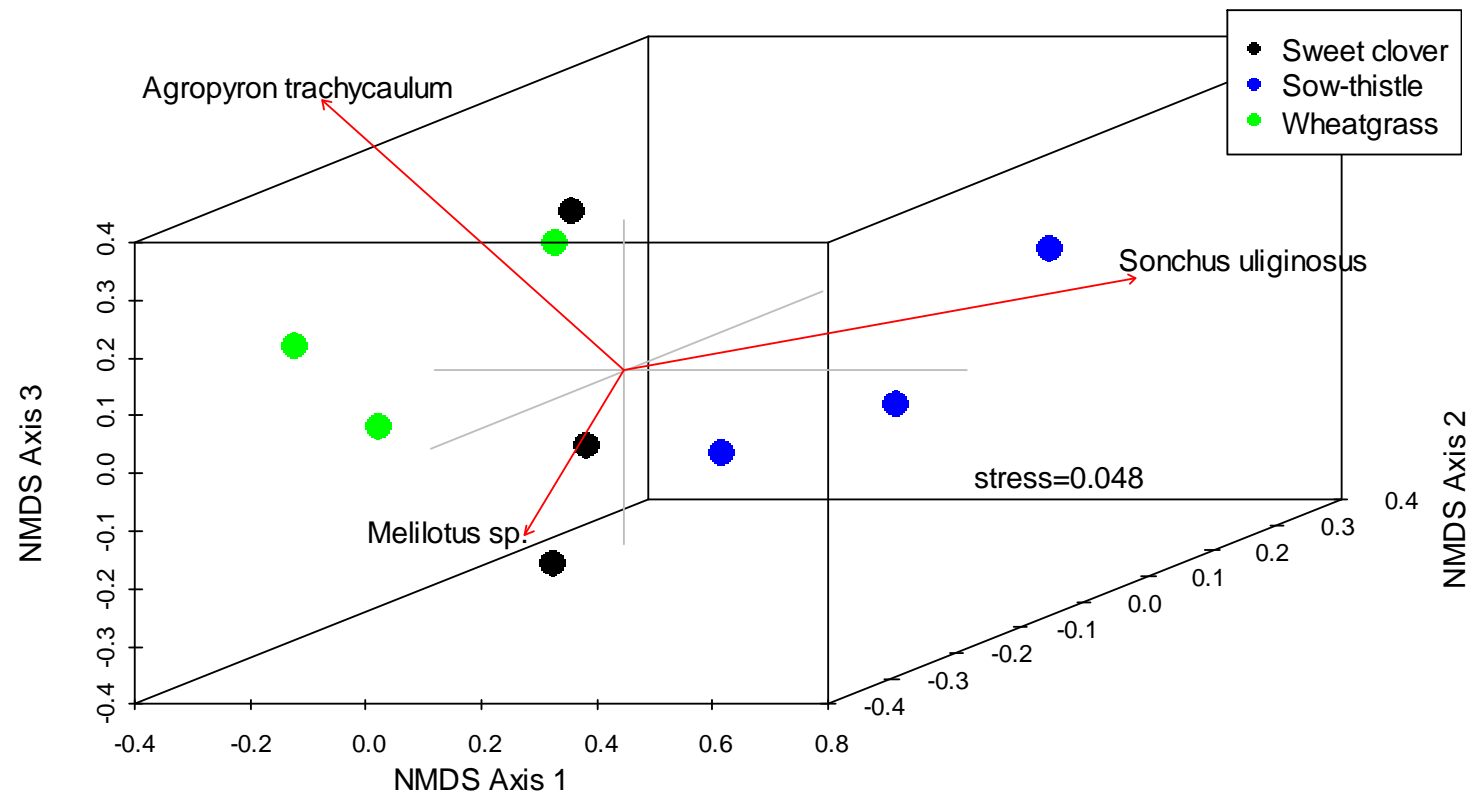

Figure 5. NMS ordination comparing seed bank plant communities across the different surface vegetation types ( 3 dimensions). $\mathrm{S}=$ sow-thistle vegetation treatment, $\mathrm{W}=$ wheatgrass, $\mathrm{C}=$ sweet clover.

\section{$\underline{\text { Discussion }}$}

For all surface vegetation types studied there was a marked decline in the stockpile seed bank seedling abundance and species richness (except for the sow-thistle community) with depth. This is a common trend found in stockpiled soils around the world, with many studies finding that seed viability declines with stockpile depth and age (Dickie et al., 1988; Iverson and Wali, 1982; Tacey and Glossop, 1980). Dickie et al. (1988) found a higher relative seedling abundance in Derbyshire, England at the surface of the stockpile than in this study, with $80 \%$ of seedlings at the surface of a 4-year-old stockpile, compared with our $68 \%$ of seedlings germinating at the surface of the stockpile.

We also saw a reduction of viable seeds with depth in naturally occurring forests, where most of the seed bank occurs in the organic surface layers of soil (Granström, 1982; Moore and Wein, 1977; Qi and Scarratt, 1998). Whether the soil is stockpiled or not, there is only an input of seeds at the surface of the soil resulting in a higher concentration of seeds at the surface. After salvaging 
and stockpiling redistributes the seeds throughout the soil profile, there is likely germination at depth and then subsequent death due to failure to reach the surface, or fungal pathogens and predation (Bellairs and Bell, 1993; Dickie et al., 1988; Golos and Dixon, 2014; Harris and Birch, 1987; Iverson and Wali, 1982). The combination of an input of seeds at the surface of the stockpile, and loss of seeds throughout the stockpile over time could lead to the gradient in the seed bank that we are seeing.

The surface seed bank $(0-10 \mathrm{~cm})$ was influenced by surface vegetation with the dominant aboveground vegetation species being more abundant in the seed bank for their own vegetation type. For example, Sonchus arvensis was most abundant in the sow-thistle vegetation type, $A$. trachycaulum in the wheatgrass type, and Melilotus sp. in the sweet clover, when compared with other vegetation types, at $0-10 \mathrm{~cm}$. However, there was a decline in the abundance of these surface dominant species at lower depths, so in this stockpile the influence of the aboveground vegetation does not appear to apply to lower depths in the seed bank. For example, when sweet clover is dominant in the aboveground vegetation and in the surface of the seed bank it is not present below $0-10 \mathrm{~cm}$ in the seed bank.

The influence of surface vegetation on the surface seed bank is also common in unmined forest soils, as the seed bank has been found to be mainly influenced by the canopy and understory plant community seed rain, micro and structural habitat characteristics, and adjacent plant communities (Beatty, 1991; McGraw, 1987; Olano et al., 2002). At the surface of the soil, there is an input of seeds from growing plants that is not present at depth and it takes time for seeds to naturally move down the soil profile. In this case, the vegetation growing on the surface of the stockpile (wheatgrass, sow-thistle and sweet clover) are all species which can produce many seeds in one season, thus contributing significantly to the surface seed bank (Tilley et al., 2006; Stevens, 1932). As a result, the surface seed-bank community is often more comparable to recent surface vegetation and the deep soil seed bank to previous communities, with a decreasing similarity to aboveground vegetation over time at depth (Grandin and Rydin, 1998).

The influence of the aboveground vegetation on the seed bank did not appear to extend past the most abundant species (sweet clover, wheatgrass, sow-thistle). However, the percent cover of these species could help explain the discrepancy between the most abundant species in the aboveground and belowground communities. These three dominant species made up almost half 
of the average total aboveground cover, while the next abundant species did not cover more than 14\% (Table 1). The differences between the dominant species in these communities could also be due to a loss of seed viability when soil is stockpiled, damage to rhizomes, movement of seeds from neighbouring communities, and seeds that remained from the original community before disturbance. For example, Calamagrostis canadensis was a more common species in the aboveground community, but did not appear in the seed bank at all. This species mainly reproduces by rhizomes, which could be damaged when soil is stripped and stockpiled (Hitchcock and Chase, 1971). The species that were abundant in the seed bank, but not in the aboveground vegetation, like $P$. norvegica could be coming in from neighbouring communities (Beatty, 1991).

The species present lower in the seed bank seem to be capable of seed dormancy for long periods of time and producing many seeds, which increase their likelihood of being present in the seed bank for longer periods. For example, P. norvegica (rough cinquefoil), one of our most common species in the seed bank, can produce many seeds per season (13,150 seeds per plant) and has a spike in germination with increases in light levels (Taylorson and Borthwick, 1969; Werner and Soule, 1976). If this species requires light to germinate, it could explain why rough cinquefoil had high germination rates at lower depths in our study. These seeds were able to remain dormant in the stockpile, until reintroduced to light in the greenhouse. E. ciliatum and Urtica dioca are also known for being able to produce many seeds in a season, and $M$. nuda is capable of periods of seed dormancy (Bassett et al., 1977; Evans et al., 2008; Tu et al., 1998).

Most of the seedlings that germinated from our samples were native (63\%), which has also been found in other soil stockpile studies, where the percentage of native seeds was approximately $60-85 \%$ (Bellairs and Bell, 1993). However, the relative number of native species may decrease with time (Golos et al., 2016). This decline in native species could be due to the influence of aboveground vegetation. In this study, there was an increase in the number of non-native individuals and species in the seed bank at the surface of the stockpile, and the sow-thistle and sweet clover treatments had a higher non-native species cover and number of non-native species in the aboveground community. If non-native species colonize a stockpile, they could influence the seed bank and thus reduce the proportion of native seeds in the stockpile over time.

Our species richness and seedling abundances for the non-native vegetation types contradicts this theory about the impact of native species on the seed bank. In this study, having a non-native 
species (sow-thistle or sweet clover) cover the surface of the stockpile, and more non-native species in the aboveground community, resulted in no significant difference in average species richness when compared with the native vegetation type (wheatgrass) and had an overall higher percentage of native species and individuals than non-native in the seed bank just like the native vegetation type. The average seedling abundance was higher when our non-native sow-thistle species dominated the aboveground vegetation community than when the native wheatgrass

species did. Having a high native species richness and seedling abundance despite being dominated by non-native species in the aboveground community is beneficial for reclamation sites that are taken over by weedy species because it means their seed bank could still be useful for reclamation. However, in future seasons the native species richness and seedling abundance could decrease due to the seed input from the non-native species growing aboveground. Also, in many cases, when stockpiles are used for reclamation, they are older than four years and could have lost more of their native seed-bank community than our stockpile.

\section{Management Implications}

The decline in viable seeds with stockpile depth is a potential problem for reclamation because it decreases the volume of soil dense in plant propagules for reclamation. Boreal forest plant propagules are a valuable resource for reclamation, which is reflected in the preference for direct placement over using stockpiles. However, stockpiles will need to be used for future reclamation. Changing the shape of stockpiles could help to maintain the seed bank by creating flatter stockpiles which would reduce the volume at lower depths that do not have a seed input (Bell, 2004; Ghose, 2001). This technique is ideal for maintaining seed viability when soil must be stockpiled for a long period of time (Bell, 2004). However, the trade-off of this approach is that a larger area is taken up by a stockpile for a long period of time and this may not be operationally feasible, ecologically desirable, or meet regulatory requirements focused on a reduced industrial footprint.

After only four years, this stockpile had a significant decrease in the number of viable seeds with depth, assuming that there was a relatively equal density of seeds throughout at the time of placement. Stockpiling the soil for a shorter period might help to reduce the number of viable native seeds lost from the seed bank at depth. The longevity of a seed depends largely on the species, with some seeds only remaining viable for a few years (Bewley and Black, 2012). Therefore, the shorter period that a seed is stockpiled, the greater the chance that native species 
from the original undisturbed site will be able to germinate on a reclamation site, and more of the original species diversity of a site is preserved. Another approach to maximize the stockpile volume might include using thin layers for soil placement. The top of the stockpile, which has a dense seed bank and a higher proportion of native seedlings than non-native overall, could be removed first to be used for reclamation. This may allow the seed bank to re-establish on the surface of a stockpile before being stripped again later. However, getting the seed bank to reestablish after stripping could be a potential problem due to the loss of native plant propagules, and some older stockpiles may not have a diverse native seed-bank community. Another option could involve removing the top $0-5 \mathrm{~cm}$ of a soil profile and using it for direct placement on a reclamation site, and only stockpiling the seed-poor soil below (Tacey and Glossop, 1980).

Vegetation management should be considered on soil stockpiles because of the effect surface vegetation can have on the seed bank. If we encourage native species, the chances of them occurring in the stockpile seed bank increases, which then increases the chances of these species being present on reclamation sites. Being proactive about weed management to ensure a native seed bank before reclamation is best because seeding does not contribute as much to species diversity as the seed bank can (Ward et al., 1996). Some of the most common methods of control for non-native species includes mechanical removal, fire, and biological control (D'Antonio and Meyerson, 2002; Masters and Nissen, 1998). Also, using woody debris or rock on sites to increase surface roughness and provide more niches for seeds has been shown to increase species diversity and the number of native species (Brown and Naeth, 2014). However, our results show that the native species richness, and total seedling abundance of a site will not necessarily suffer as the result of non-native species growing on the surface of a stockpile, so it is possible that management of non-native species does not always have to be priority when using younger stockpiles for reclamation.

In the future, we will need to get a better idea of where in the stockpile soil profile seed densities drop off and how long soil can be stockpiled before seed viability decreases. It would also be useful to know more about the impacts of the surface vegetation community on the seedbank community to maximize the ability of surface vegetation communities to enrich the seed bank with desirable boreal forest species. 


\section{Acknowledgements}

We thank Ruth Errington, Chris Wohl, and Shelby Feniak for help in the greenhouse, Helena Magaldi, Sylvie Quideau, Brian Lanoil and Derek MacKenzie for help collecting samples in the field, and Ruth Errington for reviewing the manuscript.

\section{Funding}

This study was funded by Canadian Natural Resources Limited.

\section{$\underline{\text { Literature Cited }}$}

Alberta Environment. 2010. Guidelines for reclamation to forest vegetation in the Athabasca Oil Sands Region (2nd ed.). Terrestrial Subgroup of the Reclamation Working Group of the Cumulative Environmental Management Association Fort McMurray, Alberta.

Baldwin, A.H., K.L. McKee, and I.A. Mendelssohn. 1996. The influence of vegetation, salinity, and inundation on seed banks of oligohaline coastal marshes. American Journal of Botany: 83(4): 470-479. https://doi.org/10.1002/j.1537-2197.1996.tb12728.x

Bassett, I.J., C.W. Crompton, and W.D. Woodland. 1977. The biology of Canadian weeds: 21. Urtica dioica L. Canadian Journal of Plant Science 57(2):491-498. https://doi.org/10.4141/cjps77-072

Beatty, S.W. 1991. Colonization dynamics in a mosaic landscape: the buried seed pool. Journal of Biogeography 18:553-563. https://doi.org/10.2307/2845691

Beckingham, J.D. and J.H. Archibald. 1996. Field guide to ecosites of Northern Alberta Vol. 5. Natural Resources Canada, Canadian Forest Service, Northern Forestry Centre, Edmonton, Alberta. Special Report 5.

Bell, L.C. 2004. Construction and Protection of New Soils in Diverse Biogeographic Zones: The Challenge for Successful Rehabilitation in the Australian Mining Industry. 13th International Soil Conservation Organisation Conference. Brisbane, Australia. 402:1-8.

Bellairs, S.M. and D.T. Bell. 1993. Seed Stores for Restoration of Species- Rich Shrubland Vegetation Following Mining in Western Australia. Restoration Ecology 1(4):231-240. https://doi.org/10.1111/j.1526-100X.1993.tb00032.x 
Bewley, J.D. and M. Black. 2012. Physiology and biochemistry of seeds in relation to germination: volume 2: viability, dormancy, and environmental control. Springer Science and Business Media. https://doi.org/10.1007/978-3-642-68643-6

Brown, D. and R. Hallman. 1984. Reclaiming disturbed lands. US Dept. of Agriculture, Forest Service, Equipment Development Center, Missoula, Mont. https://books.google.ca/books?hl=en\&lr=\&id=qKrxZ87P0XQC\&oi=fnd\&pg=PP5\&dq=Bro $\underline{\text { wn, }+ \text { D., }+ \text { and }+ \text { Hallman, }+ \text { R.+1984.+Reclaiming+disturbed+lands.+US+Dept.+of+Agriculture }}$ „+Forest+Service,+Equipment+Development+Center.\&ots=eL0WlidyMJ\&sig=oFm7e95Zji VqIri3ih1DZfNFRAY\#v=onepage $\& \mathrm{q}=\mathrm{doi} \& \mathrm{f}=\mathrm{false}$

Brown, R.L. and M.A. Naeth. 2014. Woody debris amendment enhances reclamation after oil sands mining in Alberta, Canada. Restoration Ecology 22:40-48. https://doi.org/10.1111/rec.12029

Busby, R. 2014. Native Vegetation Establishment for IDOT Erosion Control Best Management Practices. Illinois Center for Transportation/Illinois Department of Transportation, Illinois.

D'Antonio, C.A. and L.A. Meyerson. 2002. Exotic plant species as problems and solutions in ecological restoration: a synthesis. Restoration Ecology 10:703-713. https://doi.org/10.1046/j.1526-100X.2002.01051.X

Dickie, J.B., K.H. Gajjar, P. Birch, and J.A. Harris. 1988. The survival of viable seeds in stored topsoil from opencast coal workings and its implications for site restoration. Biological conservation 43(4):257-265. https://doi.org/10.1016/0006-3207(88)90119-X

Evans, J., T. Luna, and D. Wick. 2004. Propagation protocol for production of container Mitella nuda L. plants (116 ml containers). USDI National Park Service, Glacier National Park. Native Plant Network, University of Idaho, College of Natural Resources, Forest Research Nursery, Moscow, Idaho.

http://www.nativeplantnetwork.org/Network/ViewProtocols.aspx?ProtocolID=208 (accessed June 12, 2013).

Fyles, J.W. (1989). Seed bank populations in upland coniferous forests in central Alberta. Canadian Journal of Botany 67: 274-278. https://doi.org/10.1139/b89-039 
Ghose, M.K. 2001. Management of Topsoil for Geologic Environmental Reclamation of Coal Mining Areas. Environmental Geology 40:1405-1410. https://doi.org/10.1007/s002540100321

Ghose, M.K. 2004. Effect of opencast mining on soil fertility. Journal of Scientific and Industrial Research 63:1006-1009.

Golos, P.J. and K.W. Dixon. 2014. Waterproofing topsoil stockpiles minimizes viability decline in the soil seed bank in an arid environment. Restoration Ecology 22(4):495-501. https://doi.org/10.1111/rec.12090

Golos, P.J., K.W. Dixon, and T.E. Erickson. 2016. Plant recruitment from the soil seed bank depends on topsoil stockpile age, height, and storage history in an arid environment. Restoration Ecology 24(S2). https://doi.org/10.1111/rec.12389

Grandin, U. and H. Rydin. 1998. Attributes of the seed bank after a century of primary succession on islands in Lake Hjälmaren, Sweden. Journal of Ecology 86(2):293-303. https://doi.org/10.1046/j.1365-2745.1998.00252.x

Granström, A. 1982. Seed banks in five boreal forest stands originating between 1810 and 1963. Canadian Journal of Botany 60:1815-1821. https://doi.org/10.1139/b82-228

Harper, J.L. 1977. Population biology of plants. Academic Press, London, England.Harris, J. A., and Birch, P. 1987. The effects on topsoil of storage during opencast mining operations. In: Journal of the Science of Food and Agriculture. John Wiley and Sons LTD, Baffins Lane Chichester, W Sussex, England PO19 1UD. p. 220-221.

Hitchcock A.S. and A. Chase. 1971. Manual of the grasses of the United States. Dover, New York. Manual of the grasses of the United States. 2nd ed. Dover, New York.

Iverson, L.R. and M.K. Wali. 1982. Buried, viable seeds and their relation to revegetation after surface mining. Journal of Range Management 35:648-652. https://doi.org/10.2307/3898656

Kellman, M.C. 1970. The viable seed content of some forest soil in coastal British Columbia. Canadian Journal of Botany 48: 1383-1385. https://doi.org/10.1139/b70-209 
Koch, J.M., S.C. Ward, C.D. Grant, and G.L. Ainsworth 1996. Effects of bauxite mine restoration operations on topsoil seed reserves in the jarrah forest of Western Australia. Restoration Ecology, 4(4):368-376. https://doi.org/10.1111/j.1526-100X.1996.tb00189.x

Kramer, N.B. and F.D. Johnson. 1987. Mature forest seed banks of three habitat types in central Idaho. Canadian Journal of Botany 65(9):1961-1966. https://doi.org/10.1139/b87-269

Lanoue, A. and C. Qualizza. 2000. LFH and shallow mineral horizons as inoculants on reclaimed areas to improve native species catch. 1999 Status Report. Syncrude Canada Ltd., Fort McMurray, Alberta, Canada.

MacKenzie, D. 2012. Best Management Practices for Conservation of Reclamation Materials in the Mineable Oil Sands Region of Alberta. Terrestrial Subgroup, Best Management Practices Task Group of the Reclamation Working Group of the Cumulative Environmental Management Association, Fort McMurray, AB. March 9, 2011.

MacKenzie, D.D. 2013. Oil sands mine reclamation using boreal forest surface soil (LFH) in northern Alberta. Ph.D. Diss, University of Alberta).

MacKenzie, D.D. and M.A. Naeth. 2007. Assisted natural recovery using a forest soil propagule bank in the Athabasca oil sands. Seeds Biology, Development and Ecology, 374-382.

Masters, R.A. and S.J. Nissen. 1998. Revegetating leafy spurge (Euphorbia esula)-infested rangeland with native tallgrasses. Weed Technology 12:381-390. https://doi.org/10.1017/S0890037X00043979

McGraw, J.B. 1987. Seed-bank properties of an Appalachian sphagnum bog and a model of the depth distribution of viable seeds. Canadian Journal of Botany 65: 2028-2035.https://doiorg.login.ezproxy.library.ualberta.ca/10.1139/b87-277

McMillan, R., S.A. Quideau, M.D. MacKenzie, and O. Biryukova. 2007. Nitrogen Mineralization and Microbial Activity in Oil Sands Reclaimed Boreal Forest Soils. Journal of environmental quality 36(5):1470-1478. https://doi.org/10.2134/jeq2006.0530

Moore, R.P. 1972. In: E.H. Roberts, editor, Effects of mechanical injuries on viability. Springer, Dordrecht, p. 94-113. https://doi.org/10.1007/978-94-009-5685-8_4 
Journal American Society of Mining and Reclamation, 2019 Vol.8, No.1

Moore, J.M. and R.W. Wein. 1977. Viable seed populations by soil depth and potential site recolonization after disturbance. Canadian Journal of Botany 55(18):2408-2412. https://doi.org/10.1139/b77-274

Moss, E.H. and J.G. Packer. 1983. Flora of Alberta: a manual of flowering plants, conifers, ferns, and fern allies found growing without cultivation in the Province of Alberta, Canada. University of Toronto Press, Toronto, Canada.

Olano, J., I. Caballero, N.A. Laskurain, J. Loidi, and A. Escudero. 2002. Seed bank spatial pattern in a temperate secondary forest. Journal of vegetation science 13(6):775-784. https://doi.org/10.1658/1100-9233(2002)013[0775:SBSPIA]2.0.CO;2

Pinno, B.D., S.M. Landhäusser, M.D. MacKenzie, S.A. Quideau, and P.S. Chow. 2012. Trembling aspen seedling establishment, growth and response to fertilization on contrasting soils used in oil sands reclamation. Canadian Journal of Soil Science 92(1):143-151. https://doi.org/10.1139/CJSS2011-004

Qi, M. and J.B. Scarratt. 1998. Effect of harvesting method on seed bank dynamics in a boreal mixed wood forest in northwestern Ontario. Canadian Journal of Botany 76(5):872-883. https://doi.org/10.1139/b98-061

R Core Team (2017). R: A language and environment for statistical computing. R Foundation for Statistical Computing, Vienna, Austria. URL https://www.R-project.org/ .

Rooney, R.C., S.E. Bayley, and D.W. Schindler. 2012. Oil sands mining and reclamation cause massive loss of peatland and stored carbon. Proceedings of the National Academy of Sciences 109(13):4933-4937. https://doi.org/10.1073/pnas.1117693108

Rydgren, K. and G. Hestmark. 1997. The soil propagule bank in a boreal old-growth spruce forest: changes with depth and relationship to aboveground vegetation. Canadian Journal of Botany 75(1):121-128. https://doi.org/10.1139/b97-014

Scoles-Sciulla, S. J. and L.A. DeFalco. 2009. Seed reserves diluted during surface soil reclamation in eastern Mojave Desert. Arid Land Research and Management 23(1):1-13. https://doi.org/10.1080/15324980802598698 
Stevens, O.A. 1932. The number and weight of seeds produced by weeds. Am. J. Bot. 19(9):184794. https://doi.org/10.2307/2436042

Tacey, W.H. and B.L. Glossop. 1980. Assessment of topsoil handling techniques for rehabilitation of sites mined for bauxite within the jarrah forest of Western Australia. Journal of Applied Ecology 17(1):195-201. https://doi.org/10.2307/2402974

Taylorson, R.B. and H.A. Borthwick. 1969. Light filtration by foliar canopies: significance for light-controlled weed seed germination. Weed Science 17(1):48-51. https://doi.org/10.1017/S0043174500030873

Tu, M., J.H. Titus, S. Tsuyuzaki, and R. del Moral. 1998. Composition and dynamics of wetland seed banks on Mount St. Helens, Washington, USA. Folia Geobotanica, 33(1):3. https://doi.org/10.1007/BF02914927

Tilley, D.J., D. Ogle, L. St. John, L. Holzworth, W. Crowder, and M. Majerus. 2006. Slender Wheatgrass Plant Guide. USDA NRCS. https://plants.usda.gov/plantguide/pdf/pg_eltrt.pdf (accessed May 31, 2018).

Ward, S.C., J.M. Koch, and G.L. Ainsworth. 1996. The effect of timing of rehabilitation procedures on the establishment of a jarrah forest after bauxite mining. Restoration ecology, 4(1), 19-24. https://doi.org/10.1111/j.1526-100X.1996.tb00103.x

Werner, P.A. and J.D. Soule. 1976. The Biology of Canadian Weeds.: 18. Potentilla recta L., P. norvegica L., and P. argentea L. Canadian Journal of Plant Science 56(3): 591-603. https://doi.org/10.4141/cjps76-095

Wilson, S.D., D.R. Moore, and P.A. Keddy. 1993. Relationships of marsh seed banks to vegetation patterns along environmental gradients. Freshwater Biology, 29 (3): 361-370. https://doi.org/10.1111/j.1365-2427.1993.tb00770.x 